ORIGINAL ARTICLE

\title{
Early Decompressive Craniectomy: A Life Saving Option in Closed Head Trauma
}

\author{
MALIK LIAQAT ALI JALAL ${ }^{1}$, ATTA UR REHMAN², MUHAMMAD SHAUKAT FAROOQ ${ }^{3}$, WAJAHAT HUSSAIN ${ }^{4}$ \\ ${ }^{1}$ Assistant Prof. Neurosurgery, DG Khan Medical College, Dera ghazi Khan \\ ${ }^{2}$ Senior Registrar, Neurosurgery, DG Khan Medical College, Dera ghazi Khan \\ ${ }^{3}$ Senior Registrar, Neurosurgery, DG Khan Medical College, Dera ghazi Khan \\ ${ }^{4}$ Demonstrator, Community Medicine, Quaid e Azam Medical College, Bahawalpur \\ Correspondence to Dr. Malik Liaqat Ali Jalal, Assistant Prof. Neurosurgery
}

\begin{abstract}
Aim: To determine outcome and factors associated with outcome among patients with closed head injury who underwent decompressive craniectomy.

Methodology: Cross sectional analytical study conducted in Neurosurgery Department of teaching hospital Dera Ghazi Khan from January, 2021 to June, 2021. Total 105 patients fulfilling the inclusion criteria were enrolled in the study.

Approval of ethical review committee was obtained. All the patients with closed head injury which underwent decompressive craniectomy were included. Socio demographic profile, mode of injury, Glasgow Coma Scale (GCS) at admission time, pupillary reaction and timing from hospital admission to surgery, duration of surgery, length of hospital stay and occurrence of CSF leakage was noted. SPSS version 22 was used for data entry and analysis.

Results: Head injury was more common in males. $43.8 \%$ cases admitted with GCS score between 3-8 and with head injury by road traffic accident. Leakage of CSF was recorded in $13.3 \%$ patients. Mortality was recorded in $18.1 \%$ patients. GCS at time of admission, time elapsed between admission and surgery and duration of surgery was significantly associated with the outcome.

Conclusion: Early decompressive craniectomy significantly reduce death rate in patients with closed head injury. Keywords: Craniectomy, Outcome, Glasgow coma scale
\end{abstract}

\section{INTRODUCTION}

Traumatic brain injuries will be major cause of mortality in future globally. In decompressive craniotomy, portion of skull is removed thus relieving the pressure on brain tissue. A drill is used by the surgeon along with bone saw to cut it. ${ }^{1}$ Traumatic brain injury is the leading cause of decompressive craniectomy but brain surgery is also associated with various complications. People who undergo a decompressive craniectomy are already in critical condition due to traumatic brain injury. ${ }^{2}$ Rehabilitation can help people regain as much brain function as possible. This might include speech therapy, physical therapy, and exercise therapy ${ }^{3}$.

\section{METHODOLOGY}

This cross sectional analytical study was conducted in Neurosurgery department of teaching hospital Dera Ghazi Khan from January, 2021 to June, 2021. Total 105 patients fulfilling the inclusion criteria were enrolled in the study. Approval from ethical review committee of institute was obtained. All the patients above the age of 14 years with closed head injury which underwent decompressive craniectomy were included in the study. Patients who had neurological deficits before the traumatic event and those having surgical lesions in other organs or systems were excluded from the study.

All the patients with traumatic brain injury were assessed by neurosurgeon. Socio demographic profile, mode of injury, Glasgow Coma Scale (GCS) score at the time of admission, pupillary reaction, lesions on computed

Received on 17-04-2021 Accepted on 27-08-2021 tomography (CT) of the head, timing from hospital admission to surgery, duration of the surgery, post-surgical length of stay in hospital and CSF leakage was noted. The data was analyzed by using SPSS version 22 . The outcome of patients was determined according to the Glasgow Outcome Scale (GOS) score at the time of discharge. Unfavorable outcome comprised of group 2 and 3 on Glasgow outcome score (GOS) and group 4 and 5 on GOS comprised of favorable outcome.

\section{RESULTS}

The detail of results is given in tables $1,2,3,4$

Table 1: Socio demographic profile of patient underwent decompressive cranietcomy

\begin{tabular}{|l|l|l|}
\hline Variables & $\mathbf{n}=$ & $\%$ age \\
\hline Age (years) & & \\
$15-30$ & 61 & $58.1 \%$ \\
$31-45$ & 25 & $23.8 \%$ \\
$>45$ & 19 & $18.1 \%$ \\
\hline Gender & & \\
Male & 93 & $88.6 \%$ \\
Female & 12 & $11.4 \%$ \\
\hline Causes of injury & & \\
Roadside accident & 69 & $65.7 \%$ \\
Fall & 19 & $18.1 \%$ \\
Assault & 17 & $16.2 \%$ \\
\hline GCS at admission & & \\
$13-15$ & 26 & $24.8 \%$ \\
$09-12$ & 33 & $31.4 \%$ \\
$03-08$ & 46 & $43.8 \%$ \\
\hline Pupil examination & & \\
Symmetric and reactive & 70 & $66.7 \%$ \\
One reactive & 24 & $22.8 \%$ \\
Both Non-reactive & 11 & $10.4 \%$ \\
\hline Time of admission and surgery & & \\
$1-5$ hours & 49 & $46.7 \%$ \\
$6-12$ hours & 21 & $20.0 \%$ \\
\hline
\end{tabular}




\begin{tabular}{|l|l|l|}
\hline$>12$ hours & 35 & $33.3 \%$ \\
\hline Duration of surgery & & \\
$<3$ hours & 31 & $29.5 \%$ \\
$3-6$ hours & 62 & $59.1 \%$ \\
$>6$ hours & 12 & $11.4 \%$ \\
\hline Hospital stay & & \\
$<10$ days & 46 & $43.8 \%$ \\
$10-20$ days & 27 & $25.7 \%$ \\
$>20$ days & 32 & $30.5 \%$ \\
\hline CSF leakage & & \\
Yes & 14 & $13.3 \%$ \\
No & 91 & $86.7 \%$ \\
\hline
\end{tabular}

Table 2: Outcome of patients underwent decompressive cranietcomy

\begin{tabular}{|l|l|l|}
\hline Outcome & $\mathbf{n}=$ & $\%$ age \\
\hline Favorable & 51 & $48.6 \%$ \\
\hline Not favorable & 35 & $33.3 \%$ \\
\hline Death & 19 & $18.1 \%$ \\
\hline Total & 105 & $100 \%$ \\
\hline
\end{tabular}

Table 3: Association of Socio demographic profile underwent decompressive cranietcomy with outcome

\begin{tabular}{|c|c|c|c|c|}
\hline \multirow[t]{2}{*}{ Variables } & \multicolumn{3}{|c|}{ Outcome } & \multirow[t]{2}{*}{$P$ value } \\
\hline & Favorable & Not favorable & Death & \\
\hline $\begin{array}{l}\text { Age (years) } \\
15-30 \\
31-45 \\
>45\end{array}$ & $\begin{array}{l}38(74.5 \%) \\
08(15.6 \%) \\
05(09.8 \%)\end{array}$ & $\begin{array}{l}13(37.1 \%) \\
13(37.1 \%) \\
09(25.8 \%)\end{array}$ & $\begin{array}{l}10(52.6 \%) \\
04(21.1 \%) \\
05(26.3 \%)\end{array}$ & $<0.01$ \\
\hline $\begin{array}{l}\text { Gender } \\
\text { Male } \\
\text { Female }\end{array}$ & $\begin{array}{l}47(92.2 \%) \\
04(07.8 \%)\end{array}$ & $\begin{array}{l}29(82.9 \%) \\
06(17.1 \%)\end{array}$ & $\begin{array}{l}17(89.5 \%) \\
02(10.5 \%)\end{array}$ & 0.40 \\
\hline $\begin{array}{l}\text { Causes of injury } \\
\text { Roadside accident } \\
\text { Fall } \\
\text { Assault }\end{array}$ & $\begin{array}{l}45(88.3 \%) \\
04(07.8 \%) \\
02(03.9 \%)\end{array}$ & $\begin{array}{l}23(65.7 \%) \\
07(20.0 \%) \\
05(14.3 \%)\end{array}$ & $\begin{array}{l}01(05.3 \%) \\
08(42.1 \%) \\
10(52.6 \%)\end{array}$ & $<0.01$ \\
\hline $\begin{array}{l}\text { GCS at admission } \\
13-15 \\
09-12 \\
03-08\end{array}$ & $\begin{array}{l}19(37.3 \%) \\
10(19.6 \%) \\
22(43.1 \%)\end{array}$ & $\begin{array}{l}04(11.4 \%) \\
14(40.0 \%) \\
17(48.6 \%) \\
\end{array}$ & $\begin{array}{l}03(15.8 \%) \\
09(47.4 \%) \\
07(36.8 \%)\end{array}$ & 0.02 \\
\hline $\begin{array}{l}\text { Pupils } \\
\text { Symmetric and reactive } \\
\text { One reactive } \\
\text { Both Non-reactive }\end{array}$ & $\begin{array}{l}37(72.5 \%) \\
13(25.5 \%) \\
01(02.0 \%)\end{array}$ & $\begin{array}{l}20(57.1 \%) \\
09(25.7 \%) \\
06(17.2 \%)\end{array}$ & $\begin{array}{l}13(68.4 \%) \\
02(10.5 \%) \\
04(21.1 \%)\end{array}$ & 0.05 \\
\hline $\begin{array}{l}\text { Time of admission and surgery } \\
1-5 \text { hours } \\
6-12 \text { hours } \\
>12 \text { hours }\end{array}$ & $\begin{array}{l}30(58.8 \%) \\
12(23.5 \%) \\
09(17.7 \%)\end{array}$ & $\begin{array}{l}13(37.1 \%) \\
07(20.0 \%) \\
15(42.9 \%)\end{array}$ & $\begin{array}{l}06(31.5 \%) \\
02(10.5 \%) \\
11(58.0 \%)\end{array}$ & 0.01 \\
\hline $\begin{array}{l}\text { Duration of surgery } \\
<3 \text { hours } \\
3-6 \text { hours } \\
>6 \text { hours }\end{array}$ & $\begin{array}{l}19(37.2 \%) \\
26(51.0 \%) \\
06(11.8 \%)\end{array}$ & $\begin{array}{l}03(08.6 \%) \\
29(82.8 \%) \\
03(08.6 \%)\end{array}$ & $\begin{array}{l}09(47.4 \%) \\
07(36.8 \%) \\
03(15.8 \%)\end{array}$ & $<0.01$ \\
\hline
\end{tabular}

\section{DISCUSSION}

Mean age of the patients was $32 \pm 16.4$ years and $58.1 \%$ were between 15-30 years of age which indicates than young people are mostly affected in traumatic brain injuries. In contrast to these findings, Skansar $\mathrm{O}$ et $\mathrm{al}^{4}$ revealed that mean age of patients with traumatic brain injury was $52 \pm 13.8$ years which is higher. This difference in age of the patients may be due to social norms. Our findings are similar with the results of Ullah $\mathrm{S}$ et $\mathrm{al}^{5}$ in which majority of the patients with traumatic head injury were in young age group. Our study findings showed that males are mostly involved in road traffic accidents which are in agreement with results of Bhatti JA et $\mathrm{al}^{6}$ in which most of the patients with head injury were males. $43.8 \%$ of the patients admitted in the hospital with GCS score between 3 to 8 which is similar to the findings of Siddiqui $\mathrm{E}_{\text {et }} \mathrm{al}^{7}$ in which GCS score of $42 \%$ patients with head injury was $<8$ at the time of admission. The most common cause of head injury in our study was road traffic accident which is in accordance with the findings of Junaid $\mathrm{M}$ et $\mathrm{al}^{8}$. Leakage of CSF was recorded in only $13.3 \%$ patients.

Our study findings reveled that outcome was favorable in almost half of the patients with closed head injury who underwent decompressive craniectomy and mortality was recorded in $18.1 \%$ patients. The fatality rate in our study is much lower than study conducted by Silva $\mathrm{AC}$ et $\mathrm{al}^{9}$ in which $35.1 \%$ patient with closed head injury died.

GCS at the time of admission, time elapsed between admission and surgery and duration of surgery was found to be significantly associated with the outcome among patients of closed head injury. Our findings are in agreement with findings of Saade $\mathrm{N}$ et $\mathrm{al}^{10}$ in which socio demographic profile of patients was similar.

\section{CONCLUSION}

It is concluded that early decompressive craniectomy significantly reduce death rate in patients with closed head injury.

Conflict of interest: Nil

\section{REFERENCES}

1. Murray CJ, Lopez AD. Alternative projections of mortality and disability by cause 1990-2020: Global Burden of Disease Study. Lancet. 1997;349(9064):1498-504.

2. Honeybul S. Complications of decompressive craniectomy for head injury. Journal of Clinical Neuroscience. 2010 Apr $1 ; 17(4): 430-5$. 
3. Honeybul S, Ho KM, Gillett GR. Reconsidering the role of decompressive craniectomy for neurological emergencies. $J$ Crit Care. 2017;39:185-9.

4. Skaansar O, Tverdal C, Rønning PA, Skogen K, Brommeland T, Røise O, Aarhus M, Andelic N, Helseth E. Traumatic brain injury-the effects of patient age on treatment intensity and mortality. BMC neurology. 2020 Dec;20(1):10-15.

5. Ullah S, Ayaz SB, Moukais IS, Qureshi AZ, Alumri T, Wani TA, Aldajani AA. Factors affecting functional outcomes of traumatic brain injury rehabilitation at a rehabilitation facility in Saudi Arabia. Neurosciences Journal. 2020 Jul 1;25(3):16975.

6. Bhatti JA, Stevens K, Mir MU, Hyder AA, Razzak JA. Emergency care of traumatic brain injuries in Pakistan: a multicenter study. BMC emergency medicine. 2015 Dec;15(2):1-7.
7. Siddiqui EU, Waheed S, Perveen F, Daniyal M, Khan MA, Siddiqui S, Siddiqui Z. Clinical outcome of paediatric patients with traumatic brain injury (TBI) receiving 3\% hypertonic saline (HTS) in the emergency room of a tertiary care hospital. JPMA. 2019 Nov;16:76-79.

8. Junaid M, Mamoon-Ur-Rashid AA, Tahir A, Bukhari SS, Kalsoom A. Changing spectrum of traumatic head injuries: Demographics and outcome analysis in a tertiary care referral center. J Pak Med Assoc. 2016 Jul 1;66(7):864-8.

9. Silva AC, de Oliveira Farias MA, Bem Jr LS, Valença MM, de Azevedo Filho HR. Decompressive Craniectomy in Traumatic Brain Injury: An Institutional Experience of 131 Cases in Two Years. Neurotrauma Reports. 2020 Oct 1;1(1):93-9.

10. Saade N, Veiga JCE, Cannoni LF, Haddad L, and Araujo JLV. Evaluation of prognostic factors of decompressive craniectomy in the treatment of severe traumatic brain injury. Rev. Col. Bras. Cir. 2014;41:256-262. 